\title{
Planning Of Facilities And Infrastructure In Islamic Education
}

\author{
Melda Diana Nasution, \\ Sekolah Tinggi Agama Islam Negeri Mandailing Natal \\ meldadiananasution83@gmail.com
}

\begin{abstract}
This paper describes the management of facilities and infrastructure in Islamic educational institutions. This discourse is important to describe because the education system is an interrelated component such as curriculum, materials, methods, educators, students, facilities, tools, approaches and so on. So far, the understanding of the concept of integration and interconnection between the sub-systems above is still lacking so that the learning process is not optimal. This study uses a library research method with an analytical-descriptive approach. The results of the study indicate that the management of educational facilities and infrastructure is a collaborative process for the effective use of all educational facilities and infrastructure. The purpose of managing school facilities and infrastructure is to provide professional services so that the learning process can take place effectively and efficiently. The management process of Islamic education facilities and infrastructure includes (1) Planning of Islamic education facilities and infrastructure (2) Procurement of Islamic education facilities and infrastructure (3) Inventory of Islamic education facilities and infrastructure (4) Supervision and maintenance of Islamic education facilities and infrastructure (5) Elimination school facilities and infrastructure. The conclusion of this study is that the management of facilities and infrastructure in Islamic educational institutions must be oriented to the principles of being on time, on target and effective.
\end{abstract}

Keywords: facilities and infrastructure; Islamic education.

\section{INTRODUCTION}

Education has a wider scope than learning, and learning is a part of education itself. Simply put, education is a conscious and deliberate effort to mature, through values that are transformed to students. While learning is a conscious and deliberate effort to mature students through the transformation of knowledge. The success of an education is influenced by the success of the learning process in it, and the success of learning is determined by various components that are interrelated with each other.

The demand for the readiness of Human Resources resulting from the education sector cannot be separated from the existence of educational facilities and infrastructure that are indeed needed in the education and learning process. Educational facilities and infrastructure are important instruments in education and are one of the eight National Education Standards. The success of educational programs in schools is strongly influenced by the condition of educational facilities and infrastructure owned by schools and the optimization of their management and utilization (Matin dan Nurhattati Fuad, 2016).

The education system is a series of sub-systems or elements of education that are interrelated in realizing its success. There are goals, curriculum, materials, methods, educators, students, means, tools, approaches and so on. The existence of one element requires the existence of another element, without the existence of one of these elements the educational process becomes blocked, 
resulting in failure (Mujamil Qomar, 2005).

The existence of educational facilities is absolutely necessary in the educational process, so it is included in the components that must be met in the implementation of the educational process. Without educational facilities, the educational process will experience very serious difficulties, and can even thwart education. An incident that must be avoided by all parties involved in education.

The educational process is carried out to achieve an educational goal. In order for these educational goals to be achieved, it is necessary to pay attention to everything that supports the success of the educational goals. Of all the factors supporting the success of educational goals, success in the learning process is one of the dominant factors. Because it is in the learning process that the internalization of values and cultural inheritance and norms occurs directly. Therefore, teaching and learning activities are the spearhead for achieving the inheritance of the above values. For this reason, it is very important in the learning process to create a conducive atmosphere so that students are really interested and participate in the process (Ramayulis, 2004).

In relation to efforts to create a conducive atmosphere, educational facilities and infrastructure play a very important role. So that the good and bad management of educational facilities and infrastructure will affect the learning process. The availability of facilities and infrastructure is one of the requirements in order to present a quality learning, because learning activities cannot run optimally if they are not supported by the availability of these educational facilities and infrastructure. The existence of facilities and infrastructure in schools needs to be managed properly to help achieve the educational goals that have been set. Many schools have complete educational facilities and infrastructure so that they really support the education process in schools, but this condition does not last long. The level of quality and quantity of facilities and infrastructure cannot be maintained continuously.

Meanwhile, assistance for facilities and infrastructure did not come all the time, and in the end all of them became obstacles in improving the quality of learning, also having an impact on wasting the budget in schools. Therefore, efforts are needed to manage facilities and infrastructure properly so that the quality and quantity of facilities and infrastructure can be maintained in a relatively long time (Sawaluddin, dan Muhammad Siddiq, 2020). Good management of facilities and infrastructure is expected to be a solution for efforts to manage facilities and infrastructure in schools. Management of educational facilities and infrastructure can be defined as the work process and utilization of all educational facilities and infrastructure effectively and efficiently. Management of educational facilities and infrastructure is tasked with regulating and maintaining educational facilities and infrastructure so that they can contribute to the educational process optimally and meaningfully (Mujamil Qomar, 2005).

\section{METHOD}

Qualitative research is research whose findings are obtained based on qualitative paradigms, strategies and model implementations. Meanwhile, according to Manca as quoted by Moleong, qualitative research has the following characteristics: (1) It is a German tradition based on idealism, humanism, and culturalism; (2) this research can generate theories, develop understanding, and explain complex realities; (3) Characterized by an inductive-descriptive approach; (4) takes a long time; (5) The data are in the form of descriptions, documents, field notes, photos, and pictures; (6) The informant is 
"Maximum Variety"; (7) processoriented; (8) The research has a micro context (Lexy J. Moleong, 1999). Therefore, in this study trying to find out and describe clearly about Planning Of Facilities And Infrastructure In Islamic Education

\section{RESULTS AND DISCUSSION}

Means are everything that can be used as a tool in achieving goals or objectives, tools, media. Meanwhile, infrastructure is everything that is the main support for the implementation of a business process, development, project, and so on. Management of infrastructure can be defined as a collaborative process of utilizing all educational facilities and infrastructure effectively and efficiently. This definition shows that existing facilities and infrastructure must be utilized and managed for the benefit of the learning process. The management of these facilities and infrastructure is intended so that their use can run effectively and efficiently. Management of educational facilities and infrastructure is tasked with regulating and maintaining educational facilities and infrastructure so that they can contribute to the educational process in an optimal and meaningful way. These management activities include planning, procurement, monitoring, inventory storage, and elimination and structuring activities (Faisal Musa dan Sawaluddin, 2020).

The educational facilities and infrastructure in Islamic educational institutions should be managed as well as possible by following the following requirements (1) Complete, ready to use at any time, strong and durable (2) Neat, beautiful, clean, elegant, and beautiful so that it cools the view and feelings of anyone who enters the complex of Islamic educational institutions (3) Creative, innovative, responsive and varied so that it can stimulate the imagination of students (4) Has a long reach through careful planning to avoid the tendency to dismantle buildings (5)
Have a place specifically for worship and the implementation of socio-religious activities such as prayer rooms or mosques.

\section{Facilities and Infrastructure in Islamic Education}

Judging from its function or role in the implementation of the teaching and learning process, educational facilities are divided into two types, namely teaching tools and educational media. Learning tools are tools or objects that are directly used by teachers and students for learning. Learning tools consist of (1) books (2) dictionaries, the Koran (3) teaching aids (4) practical tools (5) writing utensils. The National Education Association states that media are forms of communication, both printed and audiovisual and their equipment. Educational media are everything that can be used to channel messages that can stimulate students' thoughts, feelings, attention and willingness so that it can encourage the learning process to occur in students. The types of educational media are (1) audio media (2) visual media (3) Audio-visual media (Arif S Sadiman dkk, 2003).

Educational infrastructure is divided into two, namely school buildings and school furniture. The school building consists of Theory Room, Administration/Office Room, Support Room, Environmental Infrastructure/ Infrastructure, School/Madrasah Furniture. While the furniture is a means of filling space. All equipment that is not directly related to the teaching and learning process. This means that it is not a tool used by teachers/students to explain concepts (Nurfid Junus and Sawaluddin Rukiah, Zulfan Saam, Sukendi, 2020).

The Purpose of Facilities and Infrastructure in Islamic Education

Basically the management of educational facilities and infrastructure has the following objectives. First, creating a school or madrasa that is clean, 
neat, beautiful, so that it is fun for the school or madrasa residents. Second, the availability of adequate facilities and infrastructure both in quality and quantity and relevant to the interests and needs of education (Muhammad Irwansyah, Melda Diana Nasution, Afrida Afrida, 2019). In more detail, the Malang State University Management Expert Team identified several things regarding the purpose of educational facilities and infrastructure, namely:

a. To strive for the procurement of educational facilities and infrastructure througha careful and thorough planning and procurement system, so that schools or madrasas have good facilities and infrastructure in accordance with efficient funding needs.

b. To strive for the use of school facilities and infrastructure, it must be appropriate and efficient.

c. To strive for the maintenance of educational facilities and infrastructure carefully and precisely, so that the existence of these facilities and infrastructure will always be in a ready state when they are used or needed.

So, the purpose of the management of educational facilities and infrastructure is to make an optimal contribution to the educational process in achieving the educational goals that have been set. According to Hunt Pierce, the basic principles in the management of facilities and infrastructure in schools are as follows:

a. Building land and school furniture must reflect the ideals and image of the community as stated in the philosophy and goals of education.

b. Planning of building land, and school furniture should be a reflection of a shared desire and with the consideration of a team of experts who are quite capable in the community.

c. Building land and school furniture should be adjusted adequately for the interests of students, for the sake of forming their character and being able to serve and guarantee them when studying, working, and playing according to their talents.

d. Building land and school furniture and equipment should be adapted to the interests of education that originate from the interests and priorities or benefits for children/students and teachers.

e. As the person in charge must help the school program effectively train officers and choose the tools and how to use them so that they can adapt and carry out their duties according towith their functions and professions.

f. A person in charge of a school must have the skills to recognize both qualitative and quantitative and to use the proper function of the building and its equipment.

g. As the person in charge must be able to maintain and use the building and the surrounding land so that he can help the realization of health, security, happiness and beauty as well as the progress of the school and community. The buildings that are built must be pursued through careful planning so that they are used for a minimum of 25 years. For this reason, the building must be strong, durable and in the right position so that it does not get demolished and then a new building is erected in the same place in a relatively short time, because that method is a waste. It is better if the building is built multi-storey which contains benefits in addition to saving land also seems sturdy. The shape of the building should also be beautiful and have a distinctive architectural style that causes people who look at it to feel interested.

h. As the person in charge of the school not only knows the wealth of the school entrusted to him, but must pay attention to all the educational tools needed by his students. Islam Management of educational facilities and infrastructure includes planning, 
organizing,implementing, supervising, and evaluating activities for procurement, exchange, and removal of goods (Mulvono, 2010). Eliot and Mosier stated that in general the stages in the planning process are:

a) Temporarily set goals based on educational needs.

b) Determine the present state of education in a given society.

c) Formulate a specific program of goals for the school.

d) Define the course of action necessary to achieve these goals.

e) Turning plans into action.

f) Conduct continuous assessments.

g) Replanning when the assessment states this is necessary or desirable (E.B. Eliot and E.E. Mossier, 1945).

Planning is a thought process carefully to determine the activities to be carried out in the future. In preparing the needs plan, it is necessary to pay attention to the elements involved in planning such as the principal/madrasah, deputy head, head of administration, teachers and school/madrasah committees. The requirements in preparing the plan include (1) Following the guidelines (standards) on the type, quality and quantity of facilities and infrastructure in accordance with the priority scale (2) Procuring the necessary equipment with a budget ceiling (3) Providing and using operational facilities and infrastructure (4) Storing and maintaining (5) Following management procedures (6) Planning for procurement of movable goods (7) Planning for procurement of movable consumables (8) Planning for procurement of consumables (9) Planning for procurement of immovable goods (10) Calculation of study space requirements . Procurement is an activity to provide facilities and infrastructure in order to support the implementation of learning activities. Consists of books, learning tools and office equipment and furniture. All facilities and infrastructure owned must be used according to their function. For example, science practice activities must be carried out in a science laboratory. Maintenance is a continuous activity in order to keep goods in good condition or ready to use. And all items can maintain their maximum service life through the inventory process. Inventory is the recording or registration of state property (controlled by the school/madrasah) in an orderly and orderly manner according to the provisions and procedures applicable in the book in writing.

\section{CONCLUSION}

Management of educational facilities and infrastructure can be defined as a collaborative process for the effective utilization of all educational facilities and infrastructure. The purpose of managing school facilities and infrastructure is to provide professional services related to educational facilities and infrastructure so that the learning process can take place effectively and efficiently. The purpose of the management of educational facilities and infrastructure is to make an optimal contribution to the educational process in achieving the educational goals that have been set. The process of managing Islamic education facilities and infrastructure is closely related to the planning of Islamic education facilities and infrastructure, procurement of Islamic education facilities and infrastructure, inventory of Islamic education facilities and infrastructure, supervision and maintenance of Islamic education facilities and infrastructure and the elimination of school facilities and infrastructure.

\section{REFERENCE}

Barnawi dan Arifin, M. 2012. Manajemen Sarana dan Prasarana Sekolah, Yogyakarta : Ar-Ruzz Media.

Eliot, E.B. and Mossier, E.E. 1945. Organization of planning for Education, dalam 
American education in the post War Period, NSSE Chacago: Chicago Press.

Lexy J. Moleong, Metodologi Penelitian Kualitatif, Bandung: PT Remaja Rosdakarya, 1999.

Mujamil

Qomar, Epistemologi Pendidikan Islam dari Metode Rasional Hingga Metode Kritik, Jakarta: Erlangga, 2005

Mulyasa, 2002. Manajemen Berbasis Sekolah: Konsep, strategi, dan Implementasi, Bandung: PT Remaja Rosdakarya.

Mulyono, 2010. Manajemen Administrasi dan Organisasi Pendidikan, Solo: ArRuzz.

Qomar, Mujamil. 2005. Epistemologi Pendidikan Islam dari Metode Rasional

Hingga Metode Kritik, Jakarta: Erlangga.

Qomar, Mujamil. 2007. Manajemen Pendidikan Islam, Jakarta, Erlangga.

Ramayulis, 2004. Ilmu Pendidikan Islam, Jakarta: Kalam Mulia.

Sadiman, Arif S. Dkk 2003. Media Pendidikan: Pengertian Perkembangan dan Pemanfaatannya, Jakarta, Raja Grafindo Persada.

Sulistyorini, 2006. Manajemen Pendidikan Islam, Surabaya, Elkaf.

Tim Penyusun, 2007. Kamus Besar Bahasa Indonesia Edisi ke-3, Balai Pustaka, Jakarta.

Sawaluddin, dan Muhammad Siddiq, Langkah-Langkah Dan Teknik Evaluasi Hasil Belajar Pembelajaran Agama Islam. Jurnal PTK \& Pendidika, 2020. vol 6. No 1

Faisal Musa, Sawaluddin, Pembiayaan Pendidikan Islam Abad XXI: Analisis Terhadap UU Nomor 20 Tahun 2003 Tentang Pembiayaan Pendidikan Islam di Madrasah, Mataazir: Jurnal Administrasi dan
Manajemen Pendidikan, Volume : I No I JUNI 2020

Nurfid Junus and Sawaluddin Rukiah, Zulfan Saam, Sukendi, Development Of Environmental Professional Behavior Based On Natural School Study Case Natural School Of Universe (SOU), Indonesia, Ecology, Environment and Conservation, EM International, jilid, 26, 2020

Muhammad Irwansyah, Melda Diana Nasution, Afrida Afrida, Urgensi Kompetensi Kepribadian Guru dalam Sistem Pendidikan Perspektif Hadits Nabawi, Tarbiyah: Jurnal Ilmiah Pendidikan Agama Islam Volume 9. No 2. JuliDesember 2019 